\title{
The Arctic picoeukaryote Micromonas pusilla benefits from ocean acidification under constant and dynamic light
}

\author{
Emily White ${ }^{1}$, Clara J. M. Hoppe ${ }^{1}$, and Björn Rost ${ }^{1,2}$ \\ ${ }^{1}$ Alfred-Wegener-Institut, Helmholtz-Zentrum für Polar- und Meeresforschung, 27570 Bremerhaven, Germany \\ ${ }^{2}$ Fachbereich Biologie/Chemie, Universität Bremen, Leobener Strasse, 28359 Bremen, Germany \\ Correspondence: Emily White (ewhite14@msn.com)
}

Received: 28 August 2019 - Discussion started: 30 August 2019

Revised: 18 December 2019 - Accepted: 30 December 2019 - Published: 7 February 2020

\begin{abstract}
Compared to the rest of the globe, the Arctic Ocean is affected disproportionately by climate change. Despite these fast environmental changes, we currently know little about the effects of ocean acidification (OA) on marine key species in this area. Moreover, the existing studies typically test the effects of OA under constant, hence artificial, light fields. In this study, the abundant Arctic picoeukaryote Micromonas pusilla was acclimated to current ( $400 \mu \mathrm{atm})$ and future $(1000 \mu \mathrm{atm}) p \mathrm{CO}_{2}$ levels under a constant as well as a dynamic light, simulating more realistic light fields as experienced in the upper mixed layer. To describe and understand the responses to these drivers, growth, particulate organic carbon (POC) production, elemental composition, photophysiology and reactive oxygen species (ROS) production were analysed. M. pusilla was able to benefit from OA on various scales, ranging from an increase in growth rates to enhanced photosynthetic capacity, irrespective of the light regime. These beneficial effects were, however, not reflected in the POC production rates, which can be explained by energy partitioning towards cell division rather than biomass build-up. In the dynamic light regime, M. pusilla was able to optimize its photophysiology for effective light usage during both low- and high-light periods. This photoacclimative response, which was achieved by modifications to photosystem II (PSII), imposed high metabolic costs leading to a reduction in growth and POC production rates when compared to constant light. There were no significant interactions observed between dynamic light and OA, indicating that $M$. pusilla is able to maintain effective photoacclimation without increased photoinactivation under high $p \mathrm{CO}_{2}$. Based on these findings, $M$. pusilla is likely to cope well with future conditions in the Arctic Ocean.
\end{abstract}

\section{Introduction}

Alterations to the ecosystem caused by climate change are far more pronounced in the Arctic than in the rest of the world (Pörtner et al., 2014). The increase in $p \mathrm{CO}_{2}$ and concomitant decrease in seawater $\mathrm{pH}$, for instance, is particularly fast in the Arctic Ocean, which is mainly due to the higher solubility of $\mathrm{CO}_{2}$ at low water temperatures (Bates and Mathis, 2009). Many studies have investigated the effects of ocean acidification (OA) on phytoplankton and have observed species-specific responses on the physiological level (Lohbeck et al., 2012; Riebesell and Tortell, 2011; Rost et al., 2008). The negative effects of OA are thought to result from disturbed ion homeostasis under decreasing $\mathrm{pH}$, while positive responses seem to be driven by the physiological mechanisms of inorganic carbon uptake (Bach et al., 2013; Rokitta et al., 2012). Photosynthesis requires $\mathrm{CO}_{2}$ as a substrate for the carbon-fixing enzyme RuBisCO, which is however characterized by a poor substrate affinity (Badger et al., 1998). To avoid $\mathrm{CO}_{2}$ limitation arising from this, larger phytoplankton especially typically depend on carbon-concentrating mechanisms (CCMs). These CCMs involve the transport of $\mathrm{CO}_{2}$ and/or $\mathrm{HCO}_{3}^{-}$into the cell and the prevention of leakage out of the cell, as well as the expression of carbonic anhydrase, an enzyme accelerating the interconversion between $\mathrm{CO}_{2}$ and $\mathrm{HCO}_{3}^{-}$(Reinfelder, 2011). As CCMs are energetically expensive, a potential downregulation under OA may be beneficial for phytoplankton (Hopkinson et al., 2011).

Also the rates of warming are 2 to 3 times faster than the global average (Trenberth et al., 2007), a phenomenon known as Arctic amplification (Miller et al., 2010). Warming causes changes to mixing regimes in the surface ocean (Houghton 
et al., 2001), probably leading to a shoaling of the mixed layer due to increased thermal stratification and freshening caused by sea-ice melting (Steinacher et al., 2010). Furthermore, models predict that the Arctic Ocean will become more frequently nearly ice-free during the summer months (Pachauri et al., 2014). With a decrease in sea-ice cover, the primary productivity in the Arctic is expected to increase, due to higher light availability and longer growing seasons for phytoplankton (Arrigo et al., 2008). At the same time, however, annual productivity may become increasingly limited by the low nutrient supply in the Arctic Ocean, which may decrease even further due to reduced upwelling (Tremblay et al., 2015; Wassmann and Reigstad, 2011). These environmental changes in the Arctic have already led to differences in community structure and are expected to cause more dramatic regime shifts in the future (e.g. Nöthig et al., 2015; Li et al., 2009). In addition to accelerated rates of OA and warming (Pörtner et al., 2014; Trenberth et al., 2007), the Arctic is affected by strong changes in wind and weather patterns (Hu and Bates, 2018), indicating that this region is disproportionately affected by overall climate change.

Next to climate-driven changes, phytoplankton growing in the turbulent upper mixed layer must generally acclimate to the dynamics of light availability. Due to the low-light periods in such dynamic light fields, phytoplankton, on the one hand, need to increase the light harvesting efficiency, e.g. by increasing the photosynthetic pigments like chlorophyll $a$ (Chl $a$; Palmer et al., 2013). In the high-light periods, on the other hand, photoprotective mechanisms need to be activated to prevent photodamage to cells (Ragni et al., 2008). There are species-specific differences in the responses to differing light regimes, which can include changes in the number of photoprotective pigments, different photorepair mechanisms and modifications to the number of reaction centres in PSII (photosystem II; Ragni et al., 2008). Such acclimatory responses may be particularly important in the Arctic shelf seas, where high organic matter loading leads to particularly high light attenuation with depth (Granskog et al., 2012).

In the world's oceans, the picoplankton-size fraction $(<2 \mu \mathrm{m})$ is a significant contributor to overall productivity (Worden et al., 2015) and Micromonas-like picoeukaryotes are also highly abundant in the Arctic region (Lovejoy et al., 2007). Micromonas has been described as a shade-adapted species that can persist in Arctic winter darkness (Marquardt et al., 2016) with the help of mixotrophy (McKie-Krisberg and Sanders, 2014). Such low-light-adapted organisms are thought to show a lack of plasticity with regard to Chl $a$ quota and photoacclimation (Talmy et al., 2013). Smaller phytoplankton are furthermore expected to particularly benefit from reduced nutrients under enhanced stratification due to their high surface: volume ratio, which allows them to take up nutrients more efficiently (Brussaard et al., 2013). For the same reasons, picoeukaryotes may benefit from elevated $p \mathrm{CO}_{2}$ levels due to increased $\mathrm{CO}_{2}$ diffusion into the cell. Concurrently, it has been shown in different experiments that smaller phytoplankton will thrive under future OA conditions (Brussaard et al., 2013; Engel et al., 2008; Hoppe et al., 2017, 2018; Maat et al., 2014; Meakin and Wyman, 2011; Schulz et al., 2017) and are regarded as potential "winners" of climate change (e.g. Hoppe et al., 2018; Li et al., 2009; Schulz et al., 2017).

Despite their prevalence in all marine habitats, the effect of natural light variability has been mostly ignored in previous studies on OA effects. Fluctuating light has however been reported to indeed affect phytoplankton photosynthesis and growth (Falkowski, 1980; Huisman, 1999; Köhler et al., 2018; Litchman, 2000; Litchman et al., 2004). Interactive effects between dynamic light regimes and OA have been observed in the coccolithophore Gephyrocapsa oceanica, causing decreased productivity (Jin et al., 2013). Hoppe et al. (2015) reported that the Antarctic diatom Chaetoceros debilis benefitted from OA under static irradiance, while a dynamic light regime reversed this positive response. This was attributed to the fact that OA-dependent downregulation of the CCM can expose cells to oxidative stress during highlight peaks under dynamic light (Hoppe et al., 2015). Oxidative stress occurs when the production of reactive oxygen species (ROS) exceeds the defensive mechanisms for ROS reduction, leading to accumulation in the cells (Apel and Hirt, 2004). In this study, the response of M. pusilla to OA was investigated under constant and dynamic light in order to determine whether there was an interactive effect of the two environmental factors. A particular focus was laid on the physiological mechanisms that determined the observed overall responses.

\section{Materials and methods}

\subsection{Experimental setup}

Monoclonal cultures of the picoeukaryote $M$. pusilla (isolated in 2014 by Klara Wolf in Kongsfjorden, Svalbard, $79^{\circ} \mathrm{N}$ ) were grown in $1 \mathrm{~L}$ glass bottles in semi-continuous dilute batch cultures ( $\max 158000$ cells $\mathrm{mL}^{-1}$; diluted every $3-5 \mathrm{~d}$ ). The temperature remained stable at $2.6 \pm 0.2{ }^{\circ} \mathrm{C}$. The media was composed of Arctic seawater (from Hausgarten observatory, Alfred-Wegener-Institut, $78^{\circ} \mathrm{N}$, collected during an RV Maria S. Merian cruise in 2013) filtered through a $0.2 \mu \mathrm{m}$ membrane filter capsule (Sartorius Stedim Biotech, Sartobran 300) and enriched with vitamins and trace metals in accordance with the F/2 protocol (Guillard and Ryther, 1962), as well as with macronutrients in Redfield proportions (containing $100 \mu \mathrm{mol} \mathrm{L}^{-1}$ nitrate and silicate and $6.2 \mu \mathrm{mol} \mathrm{L}^{-1}$ phosphate).

Both the constant and the dynamic light regime consisted of a $20: 4 \mathrm{~h}$ light: dark cycle with an average light intensity of $83 \pm 5 \mu \mathrm{mol}$ photons $\mathrm{m}^{2} \mathrm{~s}^{-1}$. The dynamic light regime varied between 0 and $590 \mu \mathrm{mol}$ photons $\mathrm{m}^{2} \mathrm{~s}^{-1}$ (Fig. 1). These light levels were calculated based on conditions 


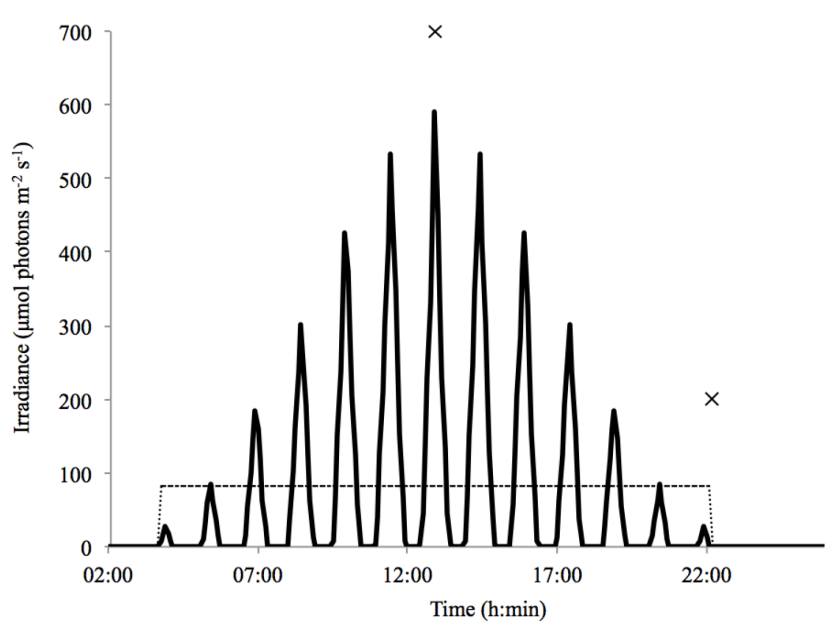

Figure 1. Light regimes plotted as a function of time over a $24 \mathrm{~h}$ period. Indicated are the dynamic light cycle (solid line) and the constant light cycle (dashed line). Time points 1 and 2 are displayed at midday and in the evening at the start of the dark period $(x)$.

typically observed in the Arctic Kongsfjorden (Svalbard, $79^{\circ} \mathrm{N}$ ) in late spring, using maximum surface irradiance of $905 \mu \mathrm{mol}$ photons $\mathrm{m}^{2} \mathrm{~s}^{-1}$, a mixed-layer depth of $20 \mathrm{~m}$, an extinction coefficient of $0.35 \mathrm{~m}^{-1}$ (Clara J. M. Hoppe, unpublished results) and a vertical mixing rate of $0.011 \mathrm{~m} \mathrm{~s}^{-1}$ (Denman and Gargett, 1983). The dynamic light field acts to approximate natural light conditions, assuming homogenous mixing and diurnal changes in incoming irradiance but no weather-associated variability. Light was supplied through LED lamps (ECONLUX, Solar Stinger Sunstrip), and the dynamic light regime was regulated using a daylight controller (LED scaping light control, LiWeBe). In both setups, the light levels were monitored using a ULM-500 universal light meter with a $4 \pi$ sensor (Effeltrich), and light intensity was adjusted with neutral density screens.

The $\mathrm{CO}_{2}$ partial pressures $\left(p \mathrm{CO}_{2}\right)$ were achieved through aeration of the incubation bottles with two different $p \mathrm{CO}_{2}$ levels (400 and $1000 \mu \mathrm{atm})$ for at least $12 \mathrm{~h}$ prior to inoculation. The gas mixtures were created using a gas flow controller (CGM 2000, Umwelttechnik MCZ), which mixed pure $\mathrm{CO}_{2}$ with $\mathrm{CO}_{2}$-free air to the desired $p \mathrm{CO}_{2}$ level. The $p \mathrm{CO}_{2}$ levels were monitored using a non-dispersive infrared analyser (LI-6252, LI-COR Biosciences). The humidified gas mixtures were bubbled through a glass frit and supplied via a sterile $0.2 \mu \mathrm{m}$ PTFE filter (Midistart 2000, Sartorius Stedim). Cultures were acclimated to the respective $p \mathrm{CO}_{2}$ levels for at least five generations prior to the experiment. To minimize shifts in carbonate chemistry due to biomass production, cell densities were kept low at between 5000 and 158000 cells $\mathrm{mL}^{-1}$.

\subsection{Carbonate chemistry}

Samples for seawater $\mathrm{pH}$ were collected at the start and middle of the experiment (during mid-light phase) and at the end of the experiment (during the first hour of the dark phase). Seawater $\mathrm{pH}$ was determined potentiometrically, using a 2point-calibrated glass reference electrode (IoLine, SCHOTT Instruments) and $\mathrm{pH}$ meter ( $826 \mathrm{pH}$ mobile, Metrohm), and was reported on the NBS scale for incubation temperatures. $\mathrm{pH}$ values were temperature-corrected using the CO2SYS program (Pierrot et al., 2006) to $2{ }^{\circ} \mathrm{C}$.

The samples for dissolved inorganic carbon $\left(C_{\mathrm{T}}\right)$ measurements were gently filtered through a sterile $0.2 \mu \mathrm{m}$ Nalgene syringe filter (Nalgene, Thermo Scientific) and stored in the dark at $2{ }^{\circ} \mathrm{C}$ in $5 \mathrm{~mL}$ borosilicate bottles. The sample was subsequently analysed colorimetrically in duplicate using an autoanalyser (Seal Analytical; Stoll et al., 2001) with a reproducibility of $\pm 8 \mu \mathrm{mol} \mathrm{kg}^{-1}$ (Table 1 ). A certified reference standard material (CRM) was used to correct for measurement errors (Dickson et al., 2007). The final average $C_{\mathrm{T}}$ values were $2141 \pm 23 \mu \mathrm{mol} \mathrm{kg}{ }^{-1}$ at ambient $p \mathrm{CO}_{2}$ levels and $2209 \pm 11 \mu \mathrm{mol} \mathrm{kg}{ }^{-1}$ under high $p \mathrm{CO}_{2}$ (Table 1).

The total alkalinity $\left(A_{\mathrm{T}}\right)$ samples were gently filtered through pre-combusted $25 \mathrm{~mm}$ GF/F filters (glass microfiber filter, Whatman, GE Healthcare Life Sciences) and stored in $125 \mathrm{~mL}$ dark borosilicate bottles at $2{ }^{\circ} \mathrm{C}$. Standards and samples were equilibrated to room temperature prior to potentiometric titrations (Brewer et al., 1986) of two $25 \mathrm{~mL}$ subsamples with an autoanalyser (TitroLine alpha plus, SCHOTT Instruments). An internal standard was applied to correct for systematic errors based on measurements of CRMs, and the data were processed using TitriSoft 2.71 software. The corrected final $A_{\mathrm{T}}$ values ranged between $2194 \pm 8$ and $2215 \pm$ $5 \mu \mathrm{mol} \mathrm{kg}{ }^{-1}$ (Table 1).

The full carbonate system was calculated with a salinity of 32.2 and a temperature of $2{ }^{\circ} \mathrm{C}$ using the $\mathrm{pH}$ and $A_{\mathrm{T}}$ data with the CO2SYS program (Pierrot et al., 2006), following suggestions by Hoppe et al. (2012; Table 1). The calculations used constants of Mehrbach et al. (1973) with a refit by Dickson and Millero (1987) and a $(B)_{\mathrm{T}}$ value according to Uppström (1974). The carbonate system remained stable for the duration of the experiment; i.e. the average daily $\mathrm{pH}$ values, calculated using the start, middle and end measurements, were $8.12 \pm 0.06$ for ambient conditions and $7.82 \pm 0.03$ for high $p \mathrm{CO}_{2}$ levels.

\subsection{Growth and cellular composition}

Cell densities of $M$. pusilla were quantified using a flow cytometer (FCM; Accuri C6, BD Biosciences). Samples were analysed using live cells, where $490 \mu \mathrm{L}$ of sample was added to $10 \mu \mathrm{L}$ of $1 \mu \mathrm{m}$ microspheres fluorescent-beads solution (Fluoresbrite YG, Polysciences Inc), which acted as an internal standard. Cells were identified and counted using the FL3 and FL4 channels as well as forward scatter for $2 \mathrm{~min}$ 
Table 1. Carbonate chemistry measurements for each light and $p \mathrm{CO}_{2}$ treatment $(n=4$; mean $\pm 1 \mathrm{SD})$. The measured values are $C_{\mathrm{T}}$ (dissolved inorganic carbon), $A_{\mathrm{T}}$ (total alkalinity) and $\mathrm{pH}$ (NBS scale). $p \mathrm{CO}_{2}$ was calculated using the CO2SYS program, with $\mathrm{pH}$ and $A_{\mathrm{T}}$ as input values. The values were calculated for $2{ }^{\circ} \mathrm{C}$, with a salinity of 32.2. The nutrient levels were 6.5 and $100 \mu \mathrm{mol} \mathrm{kg}{ }^{-1}$ for $\mathrm{PO}_{4}$ and $\mathrm{Si}(\mathrm{OH})_{4}$, respectively.

\begin{tabular}{lccccc}
\hline $\begin{array}{l}\text { Light } \\
\text { treatment }\end{array}$ & $\begin{array}{c}p \mathrm{CO}_{2} \\
(\mu \mathrm{atm})\end{array}$ & $\begin{array}{c}C_{\mathrm{T}} \\
\left(\mu \mathrm{mol} \mathrm{kg}{ }^{-1}\right)\end{array}$ & $\begin{array}{c}A_{\mathrm{T}} \\
(\mu \mathrm{mol} \mathrm{kg}\end{array}$ & $\begin{array}{c}\mathrm{pH} \\
\text { NBS scale }\end{array}$ & $\begin{array}{c}p \mathrm{CO}_{2} \\
(\mu \mathrm{atm})\end{array}$ \\
\hline Constant & 400 & $2122 \pm 16$ & $2194 \pm 8$ & $8.15 \pm 0.07$ & $397 \pm 64$ \\
light & 1000 & $2202 \pm 6$ & $2215 \pm 5$ & $7.79 \pm 0.02$ & $956 \pm 49$ \\
Dynamic & 400 & $2156 \pm 15$ & $2207 \pm 8$ & $8.06 \pm 0.01$ & $492 \pm 18$ \\
light & 1000 & $2216 \pm 11$ & $2208 \pm 7$ & $7.79 \pm 0.02$ & $963 \pm 53$ \\
\hline
\end{tabular}

on slow speed with a maximum of 50000 events. Specific growth rate constants $(\mu)$ were calculated from exponential fits of cell numbers over time for each replicate bottle. Samples were measured daily within a $1 \mathrm{~h}$ time frame for consistency.

Samples for particulate organic carbon (POC) and particulate organic nitrogen (PON) were collected at the end of the batch-culture experiment during the dark phase; samples were gently filtered onto pre-combusted $25 \mathrm{~mm} \mathrm{GF/F}$ filters. Before analysis, $200 \mu \mathrm{L}$ of hydrochloric acid $(\mathrm{HCl}, 0.2 \mathrm{M})$ was added to each filter and the samples were dried at $60^{\circ} \mathrm{C}$ for at least $12 \mathrm{~h}$ to remove any inorganic carbon. The samples were analysed using an elemental analyser (Euro EA 3000, HEKAtech). The POC and PON data were corrected by subtracting blank measurements, and values were normalized using the specific cell density and volume filtered to yield cell quotas. Subsequently, production rates were calculated by multiplying the quota with the specific growth rate constant $(\mu)$ of the respective incubation.

Samples for the Chl $a$ quota were obtained at the end of the batch-culture experiment during the dark phase, by gentle filtration onto $25 \mathrm{~mm} \mathrm{GF/F} \mathrm{filters,} \mathrm{and} \mathrm{were} \mathrm{immediately} \mathrm{stored}$ at $-20^{\circ} \mathrm{C}$ until analysis. For chlorophyll extraction, $8 \mathrm{~mL}$ of $90 \%$ acetone was added to the filters and subsequently stored at $4{ }^{\circ} \mathrm{C}$ for at least $4 \mathrm{~h}$ in darkness. After centrifugation (4500 rpm for $5 \mathrm{~min}$, Sigma 4K10), samples were measured on a fluorometer (TD-700 Fluorometer, Turner Designs) before and after acidification with $\mathrm{HCl}(1 \mathrm{M})$. Chl $a$ concentrations $\left(\mu \mathrm{g} \mathrm{L}^{-1}\right)$ were calculated as in Knap et al. (1996).

\subsection{Physiological responses}

Photophysiological parameters were measured using a fast-repetition-rate fluorometer (FRRf; FastOcean sensor, Chelsea Technologies) in combination with a FastAct system (Chelsea Technologies). The fluorometer's light-emitting diodes (LEDs) were set to an emission wavelength of $450 \mathrm{~nm}$. A saturation phase of 100 flashlets on a pitch of $2 \mu \mathrm{s}$ was used, with a relaxation phase comprising 40 flashlets and a pitch of $50 \mu \mathrm{s}$. Prior to measurements, samples were dark acclimated for $15 \mathrm{~min}$, and measurements were conducted in a temperature-controlled chamber at $3{ }^{\circ} \mathrm{C}$. The maximum $\left(F_{\mathrm{m}}, F_{\mathrm{m}}^{\prime}\right)$ and minimum $\left(F_{0}, F^{\prime}\right)$ chlorophyll fluorescence in the dark and light were estimated according to iterative algorithms for induction (Kolber et al., 1998) and relaxation phases (Oxborough et al., 2012). The PSII quantum yield efficiency was estimated as $F_{\mathrm{v}} / F_{\mathrm{m}}$ using the following equation:

$F_{\mathrm{v}} / F_{\mathrm{m}}=\left(F_{\mathrm{m}}-F_{0}\right) / F_{\mathrm{m}}$.

Additional parameters were measured after dark acclimation, including the absorption cross-section size of PSII ( $\sigma_{\text {PSII }} ; \AA^{2}$. $q^{-1}$ ), the connectivity of PSII $(\rho)$ and the PSII reopening rate $(\tau ; \mathrm{ms})$, according to Kolber et al. (1998). $F_{0}^{\prime}$ was estimated after Oxborough and Baker (1997) as

$F_{0}^{\prime}=F_{0} / \frac{F_{\mathrm{v}}}{F_{\mathrm{m}}}+\frac{F_{0}}{F_{\mathrm{m}}^{\prime}}$.

Thereafter, the coefficient of photochemical quenching $\mathrm{qL}$ was calculated after Kramer et al. (2004) as

$\mathrm{qL}=\left(\left(F_{\mathrm{m}}^{\prime}-F^{\prime}\right) /\left(F_{\mathrm{m}}^{\prime}-F_{0}^{\prime}\right)\right) \cdot\left(F_{0}^{\prime} / F^{\prime}\right)$.

The electron transport rates through PSII (ETR; mol e $\left.{ }^{-}(\mathrm{molRCII})^{-1} \mathrm{~s}^{-1}\right)$ were calculated after $\mathrm{Xu}$ et al. (2017) using the following equation:

$\mathrm{ETR}=\sigma_{\mathrm{PSII}} \times \mathrm{qL} \times \mathrm{PAR}$,

where $\sigma_{\text {PSII }}$ is the absorption cross-section size of PSII, and PAR is the photosynthetically active radiation. Photosynthesis-irradiance (PI) curves were estimated at eight irradiances between 0 and $589 \mu \mathrm{mol}$ photons $\mathrm{m}^{-2} \mathrm{~s}^{-1}$. According to the model by Webb et al. (1974), the light harvesting efficiency $\left(\alpha ; \mathrm{mol}^{-} \mathrm{m}^{2}\right.$

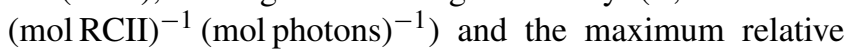
electron transport rate $\left(\mathrm{ETR}_{\max } ; \mathrm{mol}^{-}(\mathrm{mol} \mathrm{RCII})^{-1} \mathrm{~s}^{-1}\right)$ were estimated using the following equation:

$\mathrm{ETR}=\mathrm{ETR}_{\max }\left[1-e\left(\frac{-\alpha I}{\mathrm{ETR}_{\max }}\right)\right]$.

The light saturation index $\left(I_{k} ; \mu\right.$ mol photons $\left.\mathrm{m}^{-2} \mathrm{~s}^{-1}\right)$ was calculated as $\mathrm{ETR}_{\max } / \alpha$.

At the light level of $506 \mu \mathrm{mol}$ photons $\mathrm{m}^{-2} \mathrm{~s}^{-1}$, nonphotochemical quenching (NPQ) was calculated as $Y(\mathrm{NPQ})$ using calculations as described in Klughammer and Schreiber (2008):

$Y(\mathrm{NPQ})=\frac{F}{F_{\mathrm{m}}^{\prime}}-\frac{F}{F_{\mathrm{m}}}$.

Measurements of ROS for both $\cdot \mathrm{O}_{2}^{-}$free radicals and $\mathrm{H}_{2} \mathrm{O}_{2}$ were assessed using the FCM with the fluorochromes dihydroethidium (HE; D7008, Sigma-Aldrich) and dihydrorhodamine 123 (DHR123; D1054, Sigma-Aldrich), respectively. 
Methods were adapted from Prado et al. (2012), with final dye concentrations adjusted to $158.5 \mu \mathrm{M}$ for the fluorochrome $\mathrm{HE}$ and $28.87 \mathrm{mM}$ for DHR123 and an optimized incubation time of $30 \mathrm{~min}$ in the dark at $2{ }^{\circ} \mathrm{C}$. After entering the cell, the fluorochrome HE is oxidized by superoxides and subsequently binds with DNA, whereas DHR123 diffuses into the cell and accumulates in the mitochondria (Benov et al., 1998; Prado et al., 2012). To determine cell-specific concentrations, gated FL1 (505-550 nm) and FL3 (600-645 nm) detection channels were used to analyse the relative concentration of $\cdot \mathrm{O}_{2}^{-}$free radicals and $\mathrm{H}_{2} \mathrm{O}_{2}$, respectively. The ROS measurements were corrected using blank measurements and normalized to cell size using the forward scatter.

The ROS measurements were taken at two specific time points on the last day of incubation, whereas the photophysiological measurements were taken solely at time point 2 (Fig. 1). The midday measurements, referred to as time point 1 , were conducted at the highest light intensity $\left(590 \mu \mathrm{mol}\right.$ photons $\left.\mathrm{m}^{-2} \mathrm{~s}^{-1}\right)$ in the dynamic-light cycle and at the same time under the average light intensity $\left(83 \mu \mathrm{mol}\right.$ photons $\left.\mathrm{m}^{-2} \mathrm{~s}^{-1}\right)$ in the constant-light cycle. The evening measurements, referred to as time point 2, were conducted at the start of the dark period $\left(0 \mu \mathrm{mol}\right.$ photons $\left.\mathrm{m}^{-2} \mathrm{~s}^{-1}\right)$ in both the constant- and dynamiclight cycles.

\subsection{Statistical analysis}

The results are presented as means of the $n=4$ replicates with a single standard deviation. To identify significant differences between the experimental runs, two-way analysis of variance (ANOVA) tests were performed with a significance level of $P \leq 0.05$. The tests were completed using the Minitab Express statistical software (Minitab).

\section{Results}

\subsection{Growth and cellular composition}

In this study, the growth rates of $M$. pusilla were affected by both light regime and $p \mathrm{CO}_{2}$ level (Fig. 2). Growth was reduced by at least $50 \%$ in dynamic versus constant light, irrespective of $p \mathrm{CO}_{2}$ level (ANOVA, $F(13)=1840.4, p<$ $0.0001)$. In addition, growth rates significantly increased (>4\%) under elevated $p \mathrm{CO}_{2}$ levels in both light regimes (ANOVA, $F(13)=21.9, p=0.0004)$. The POC and PON quotas were not altered by changes in light regime or $p \mathrm{CO}_{2}$ levels (Table 2). The POC production rates were significantly higher in constant versus dynamic light (ANOVA, $F(12)=$ $31.2, p=0.0001)$, irrespective of the $p \mathrm{CO}_{2}$ level applied. The $\mathrm{C}: \mathrm{N}$ ratio was not significantly affected by the applied treatments. While Chl $a$ quotas decreased significantly under elevated $p \mathrm{CO}_{2}$ levels (ANOVA, $F(13)=26.4, p=0.0002$ ), there was no significant response to the light treatments applied. The applied treatments did not have a significant effect
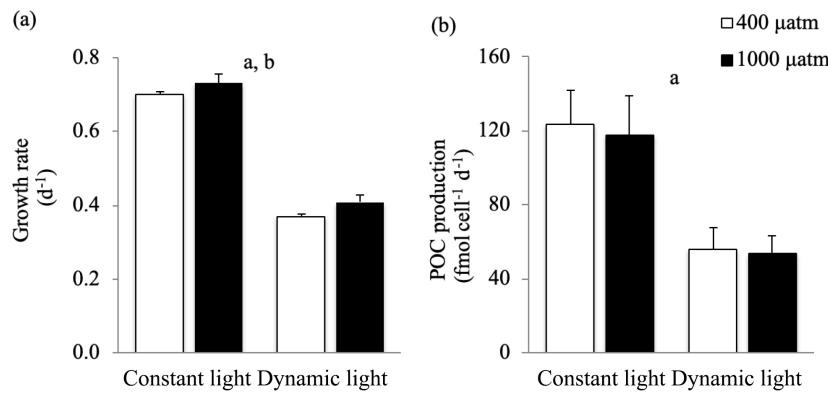

(c)

(d)
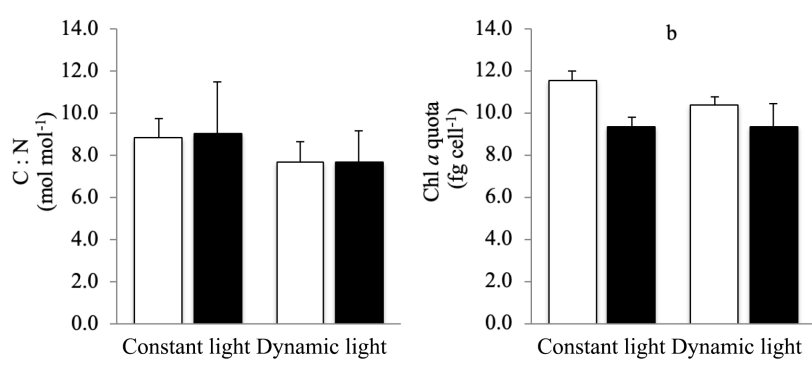

Figure 2. (a) Growth rate $\left(\mathrm{d}^{-1}\right)$, (b) POC production (fmol cell d ${ }^{-1}$ ), (c) $\mathrm{C}: \mathrm{N}$ ratio $\left(\mathrm{mol} \mathrm{mol}^{-1}\right)$, (d) chlorophyll $a$ quota (fg cell ${ }^{-1}$ ) of Micromonas pusilla under constant light and dynamic light and $p \mathrm{CO}_{2}$ levels of $400 \mu \mathrm{atm}$ (white) and $1000 \mu \mathrm{atm}$ (black; $n=4$; mean $\pm 1 \mathrm{SD}$ ). The letters indicate significant differences between treatments ( $p<0.05)$, represented as (a) light and (b) $p \mathrm{CO}_{2}$.

on the $\mathrm{C}: \mathrm{Chl} a$ ratio. For all these parameters, no significant interactive effects between the applied light and $p \mathrm{CO}_{2}$ conditions could be detected (Fig. 2; Table 2).

\subsection{Photophysiological measurements}

The FRRf measurements yielded a number of physiological parameters, most of which were significantly affected by the different light and/or $p \mathrm{CO}_{2}$ treatments applied (Table 3). The PSII quantum yield efficiency $\left(F_{\mathrm{v}} / F_{\mathrm{m}}\right)$ under dynamic light was significantly higher compared to the constant light treatment (ANOVA, $F(13)=88.5, p<0.0001)$. Even though to a lesser extent, high $p \mathrm{CO}_{2}$ levels also significantly increased $F_{\mathrm{v}} / F_{\mathrm{m}}$ (ANOVA, $F(13)=4.8, p=0.0480$; Table 3 ). The connectivity of PSIIs $(\rho)$ was higher under dynamic versus constant light (ANOVA, $F(13)=17.6, p=0.0011$ ), while there was no significant effect of $p \mathrm{CO}_{2}$. Similarly, the absorption cross section of PSII photochemistry $\left(\sigma_{\mathrm{PSII}}\right)$ was significantly higher in dynamic compared to constant light (ANOVA, $F(12)=7.0, p<0.0001$ ), irrespective of the applied $p \mathrm{CO}_{2}$ level. In addition, there was significantly less NPQ under dynamic compared to constant light (ANOVA, $F(13)=110.3, p<0.0001)$, but there was no significant $p \mathrm{CO}_{2}$ response in NPQ $(p>0.05)$. Under dynamic light, the PSII reopening rate $(\tau)$ was significantly reduced and $>5 \%$ lower when compared to constant light (ANOVA, 
Table 2. Growth and cellular composition of $M$. pusilla $(n=4$; mean \pm 1 SD), including the growth rate, POC production, POC quota, PON quota, chlorophyll $a$ quota, $\mathrm{C}: \mathrm{N}$ ratio and POC : chlorophyll $a$ ratio. Treatments include constant light and dynamic light and the two $p \mathrm{CO}_{2}$ levels of 400 and $1000 \mu \mathrm{atm}$. The letters indicate significant differences between treatments $(p<0.05)$ represented as (a) light and (b) $p \mathrm{CO}_{2}$.

\begin{tabular}{|c|c|c|c|c|c|c|c|c|}
\hline $\begin{array}{l}\text { Light } \\
\text { treatment }\end{array}$ & $\begin{array}{l}p \mathrm{CO}_{2} \\
(\mu \mathrm{atm})\end{array}$ & $\begin{array}{c}\text { Growth rate } \\
\qquad \mu\left(\mathrm{d}^{-1}\right)\end{array}$ & $\begin{array}{l}\text { POC production } \\
\left(\mathrm{fmol} \mathrm{cell}^{-1} \mathrm{~d}^{-1}\right)\end{array}$ & $\begin{array}{c}\text { POC quota } \\
\left(\text { fmol cell }^{-1}\right)\end{array}$ & $\begin{array}{c}\text { PON quota } \\
\left(\text { fmol cell }^{-1}\right)\end{array}$ & $\begin{array}{l}\text { Chl } a \text { quota } \\
\left(\text { fg cell }^{-1}\right)\end{array}$ & $\begin{array}{c}\mathrm{C}: \mathrm{N} \\
\left(\mathrm{mol} \mathrm{mol}^{-1}\right)\end{array}$ & $\begin{array}{l}\text { POC : Chl } a \\
\quad\left(\mathrm{~g} \mathrm{~g}^{-1}\right)\end{array}$ \\
\hline Constant light & 400 & $0.70 \pm 0.01$ & $124 \pm 18$ & $177 \pm 26$ & $19.2 \pm 2.3$ & $11.5 \pm 0.49$ & $8.8 \pm 0.9$ & $185 \pm 28$ \\
\hline \multirow[t]{2}{*}{ Dynamic light } & 400 & $0.37 \pm 0.01$ & $56 \pm 12$ & $151 \pm 28$ & $20.3 \pm 4.6$ & $10.4 \pm 0.39$ & $7.7 \pm 1.0$ & $175 \pm 30$ \\
\hline & 1000 & $0.41 \pm 0.02$ & $54 \pm 10$ & $132 \pm 26$ & $18.5 \pm 5.7$ & $9.3 \pm 1.07$ & $7.7 \pm 1.5$ & $172 \pm 42$ \\
\hline Significance & & $\mathrm{a}, \mathrm{b}$ & $\mathrm{a}$ & & & $\mathrm{b}$ & & \\
\hline
\end{tabular}

$F(13)=18.6, p=0.0008)$, while $\tau$ did not display a significant response to $p \mathrm{CO}_{2}$ (Table 3).

The model by Webb et al. (1974) was used to estimate $P-I$ parameters from the FRRf data. The light saturation index $\left(I_{k}\right)$ and maximum photosynthetic rate $\left(\mathrm{ETR}_{\max }\right)$ both increased significantly by $>10 \%$ under elevated $p \mathrm{CO}_{2}$ levels (ANOVA, $F(13)=11.8, p=0.0047$ for $I_{k}$ and $F(13)=$ $6.8, p=0.0214$ for ETR $_{\max }$; Table 3). While there was no significant response of $I_{k}$ to the two light treatments, ETR $\max$ was significantly higher under dynamic light compared to constant light (ANOVA, $F(13)=41.2, p<0.0001$ ). The light harvesting efficiency $(\alpha)$ was significantly reduced by high $p \mathrm{CO}_{2}$ versus ambient $p \mathrm{CO}_{2}$ levels (ANOVA, $F(13)=$ 9.6, $p=0.0084)$ and significantly higher under dynamic light versus constant light (ANOVA, $F(13)=36.0, p<$ 0.0001; Table 3).

\subsection{ROS levels}

The relative concentrations of $\cdot \mathrm{O}_{2}^{-}$free radicals and $\mathrm{H}_{2} \mathrm{O}_{2}$ were used as an indication of oxidative stress under the applied treatments (Fig. 3). At time point 1 (midday), the production of $\cdot \mathrm{O}_{2}^{-}$free radicals was not significantly changed in response to $p \mathrm{CO}_{2}$ levels or light regimes $(p>0.05)$. However, there was a significant increase in $\mathrm{H}_{2} \mathrm{O}_{2}$ production in high $p \mathrm{CO}_{2}$ versus ambient $p \mathrm{CO}_{2}$ conditions (ANOVA, $F(12)=4.8, p=0.0488$ ), irrespective of the light treatment applied. The applied treatments did not have a significant effect on the ROS levels at time point 2 (Fig. S1, in the Supplement).

\section{Discussion}

\subsection{Effective acclimation towards dynamic light imposes high metabolic costs}

In their natural environment, phytoplankton need to cope with varying light in the upper mixed layer (MacIntyre et al., 2000). Next to variation in insolation, the light fields are critically dependent on the mixed-layer depth, the light attenuation and the vertical mixing rate. In laboratory experi-
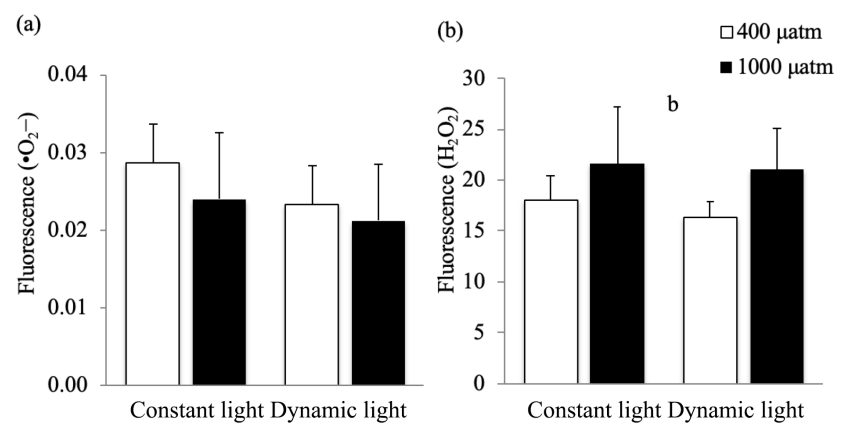

Figure 3. The relative production of (a) oxygen free radicals $\left(\cdot \mathrm{O}_{2}-\right)$ and (b) hydrogen peroxide $\left(\mathrm{H}_{2} \mathrm{O}_{2}\right)$ in Micromonas pusilla under constant light and dynamic light and $p \mathrm{CO}_{2}$ levels of $400 \mu \mathrm{\mu tm}$ (white) and $1000 \mu$ atm (black; $n=4$; mean $\pm 1 \mathrm{SD}$ ) at time point 1 . The letter $\mathrm{b}$ indicates a significant difference $(p<0.05)$ between $p \mathrm{CO}_{2}$ treatments.

ments, however, they are often exposed to an artificially constant light (Köhler et al., 2018). Simulating a dynamic light field to be more representative of an Arctic fjord, we could show that M. pusilla can photoacclimate to these more realistic variations in light availability without showing signs of high-light stress. This is supported by significantly higher PSII quantum yield efficiency $\left(F_{\mathrm{v}} / F_{\mathrm{m}}\right)$ under dynamic light (Table 3), which is commonly used as a health indicator of photosynthetic organisms, indicating successful photoacclimation to varying light intensities (Van Leeuwe and Stefels, 2007).

To achieve this photoacclimation, $M$. pusilla can apparently adjust its PSII physiology to balance photoprotection during high-light periods with sufficient absorption during low-light periods of the dynamic light field. More specifically, there were a number of changes to PSII, including a significant increase in the cross-section size of the antenna in PSII $\left(\sigma_{\mathrm{PSII}}\right)$, an increase in the connectivity between PSIIs $(\rho)$ and quicker PSII reopening rates $(\tau$; Table 3). An increase in $\sigma_{\mathrm{PSII}}$ acts to increase the absorption of light (Suggett et al., 2007), which would have been beneficial within the low-light periods of the dynamic light cycle (Schuback et al., 2017) and is supported by a significant in- 
Table 3. FRRf-based photophysiological parameters for $M$. pusilla $\left(n=4\right.$; mean \pm 1 SD). Displayed is the $F_{\mathrm{V}} / F_{\mathrm{m}}$ (dimensionless), the connectivity between PSIIs ( $\rho$; dimensionless), the absorption cross section of PSII photochemistry $\left(\sigma_{\mathrm{PSII}} ; \AA^{2} \cdot q^{-1}\right)$, the nonphotochemical quenching ( $Y(\mathrm{NPQ})$; dimensionless), the PSII reopening rate $(\tau ; \mathrm{ms})$, the maximum photosynthetic rate $\left(\mathrm{ETR}_{\mathrm{max}}\right.$; mol $\left.\mathrm{e}^{-}(\mathrm{mol} \mathrm{RCII})^{-1} \mathrm{~s}^{-1}\right)$, the light harvesting efficiency $\left(\alpha ; \text { mol }^{-} \mathrm{m}^{2} \text { (mol RCII }\right)^{-1}$ (mol photons $\left.)^{-1}\right)$ and the light saturation constant $\left(I_{k} ; \mu\right.$ mol photons $\left.\mathrm{m}^{-2} \mathrm{~s}^{-1}\right)$ for both light regimes and $p \mathrm{CO}_{2}$ levels $(\mu \mathrm{atm})$. The letters indicate significant differences between treatments $(p<0.05)$ represented as (a) light and (b) $p \mathrm{CO}_{2}$.

\begin{tabular}{lccccccccc}
\hline Light treatment & $p \mathrm{CO}_{2}$ & $F_{\mathrm{V}} / F_{\mathrm{m}}$ & $\rho$ & $\sigma_{\mathrm{PSII}}$ & $Y(\mathrm{NPQ})$ & $\tau$ & $\mathrm{ETR}_{\max }$ & $I_{k}$ & $\alpha$ \\
\hline Constant light & 400 & $0.46 \pm 0.01$ & $0.33 \pm 0.08$ & $5.2 \pm 0.1$ & $12.7 \pm 1.8$ & $617 \pm 9$ & $369 \pm 33$ & $61.4 \pm 8.0$ & $6.0 \pm 0.4$ \\
& 1000 & $0.49 \pm 0.03$ & $0.31 \pm 0.03$ & $5.5 \pm 0.1$ & $9.9 \pm 3.9$ & $600 \pm 11$ & $416 \pm 104$ & $122.7 \pm 49.7$ & $4.0 \pm 1.9$ \\
\hline Dynamic light & 400 & $0.54 \pm 0.00$ & $0.40 \pm 0.01$ & $6.7 \pm 0.4$ & $0.7 \pm 0.0$ & $573 \pm 24$ & $530 \pm 40$ & $60.1 \pm 11.8$ & $9.0 \pm 1.1$ \\
\multirow{2}{*}{ Significance } & 1000 & $0.54 \pm 0.01$ & $0.42 \pm 0.02$ & $6.8 \pm 0.4$ & $0.7 \pm 0.0$ & $569 \pm 20$ & $640 \pm 50$ & $84.2 \pm 10.4$ & $7.6 \pm 0.6$ \\
& & $\mathrm{a}, \mathrm{b}$ & $\mathrm{a}$ & $\mathrm{a}$ & $\mathrm{a}$ & $\mathrm{a}$ & $\mathrm{a}, \mathrm{b}$ & $\mathrm{b}$ & $\mathrm{a}, \mathrm{b}$ \\
\hline
\end{tabular}

crease in the light harvesting efficiency under low light $(\alpha$; Table 3). The observed increase in $\rho$ under dynamic light allows for higher flexibility in capturing electrons during lowlight phases while at the same time allowing excess excitation energy to be redistributed among PSII centres during high-light phases. This increases energy capture efficiency while protecting the PSII centres from damage through migration of excitation energy between different PSIIs, also termed the lake model (Blankenship, 2014; Trimborn et al., 2014), highlighting that M. pusilla has high potential for photoprotection. Additionally, the higher $\tau$ under dynamic versus constant light indicates more efficient drainage of electrons downstream of PSII (Kolber et al., 1998). A faster PSII reopening rate can also compensate for deactivation of functional PSII reaction centres during the high-light periods of the dynamic light field (Behrenfeld et al., 1998). The significantly lower NPQ in combination with higher ETR $_{\max }$ under dynamic versus constant light reflects photoacclimation to a higher light intensity under dynamic light, allowing effective utilization of high excitation energy without initiating highlight stress (Ragni et al., 2008). Consequently, M. pusilla exhibits the physiological plasticity needed to prevent photodamage, which otherwise can disturb the balance between production and scavenging of reactive oxygen species (ROS), causing oxidative stress and accumulation of ROS (Apel and Hirt, 2004). Indeed, dynamic light did not cause increased ROS accumulation in response to the dynamic light field (Fig. 3). Overall, M. pusilla had the capacity to sufficiently acclimate its PSII physiology to deal with dynamic light, displaying photoprotection strategies during high-light phases and upregulated light harvesting during low-light phases.

The described photoacclimation strategies appear to come at a cost, namely lowered energy transfer efficiency to biomass build-up, which is supported by significantly lower growth rates and POC production, despite an increase in $F_{\mathrm{v}} / F_{\mathrm{m}}$ and $\mathrm{ETR}_{\max }$ under dynamic compared to constant light (Fig. 2; Table 3). Our findings agree with previous studies, which also found lowered growth under a dynamic light regime (Hoppe et al., 2015; Jin et al., 2013; Mills et al.,
2010; Shatwell et al., 2012; Su et al., 2012; Wagner et al., 2006). In previous studies, acclimation to a dynamic light regime has reduced growth rates from $17 \%$ (Hoppe et al., 2015 ) to $58 \%$ (Boelen et al., 2011), which is comparable to the $47 \%$ reduction in growth rate reported in this study (Table 2; Fig. 2). It thus seems likely that such metabolic costs generally occur and that they are not particularly high in the current study. Changes in light regime strongly influence relationships between photochemistry, carbon fixation and downstream metabolic processes, optimizing light harvesting to sustain growth (Behrenfeld et al., 2008). In view of this, the significant changes to PSII physiology (Table 3) suggest that resources were channelled towards light harvesting rather than protein synthesis and biomass buildup (Talmy et al., 2013). Therefore, it can be concluded that the lower growth rates in dynamic light were caused by the high metabolic costs associated with photoacclimation to the varying light intensities and were not due to photoinhibition. Thus, our results stand in contrast to previous evidence based on which Micromonas was considered as a shade-adapted genus (Lovejoy et al., 2007) as such lowlight-adapted species are generally expected to possess limited plasticity in photoacclimative capabilities (Talmy et al., 2013).

\subsection{Picoeukaryotes benefit from ocean acidification irrespective of the light regime}

The low seawater temperatures in the Arctic enhance $\mathrm{CO}_{2}$ solubility and therefore increase $\mathrm{OA}$, from which photosynthetic organisms may benefit due to increased $\mathrm{CO}_{2}$ availability for photosynthesis (AMAP, 2018). This seems true for picoeukaryotes, as in this study $M$. pusilla showed increased growth rates and photophysiological efficiency under elevated $p \mathrm{CO}_{2}$ (Table 2; Fig. 2). These results are in line with various studies that have reported picoeukaryotes to benefit from increasing $p \mathrm{CO}_{2}$ (Brussaard et al., 2013; Hoppe et al., 2018; Meakin and Wyman, 2011; Newbold et al., 2012; Schaum et al., 2012; Schulz et al., 2017). In the current study, 
however, there was no observed increase in POC production (Fig. 2) under higher $p \mathrm{CO}_{2}$ levels, which could have been expected assuming lowered costs due to CCM downregulation (Iglesias-Rodriguez et al., 1998; Rost et al., 2008). The observed increase in growth rates nonetheless indicates beneficial OA effects potentially due to reallocation of energy liberated by eased carbon acquisition. Alternatively, the large surface : volume ratio of $M$. pusilla (cell size of $2-3 \mu \mathrm{m}$ ) may generally lower the need for an active CCM, allowing cells to depend more strongly on diffusive $\mathrm{CO}_{2}$ uptake (Falkowski and Raven, 2013). As the latter is directly linked to the $p \mathrm{CO}_{2}$ level, it could likewise explain the higher growth rates observed under elevated $p \mathrm{CO}_{2}$. In any case, the growth strategy of the investigated strain involves energy allocation into cell division rather than biomass build-up. Whether picoeukaryotes such as M. pusilla benefit from OA due to increased diffusive $\mathrm{CO}_{2}$ uptake, lowered CCM costs or both remains to be tested.

To further explain the increase in growth rate under elevated $p \mathrm{CO}_{2}$, it is essential to look into the upstream physiological parameters. There was a significant increase in $\mathrm{ETR}_{\text {max }}$ under OA (Table 3), which indicates an increase in photosynthetic capacity. Previous studies on picoeukaryotes have reported variable results, displaying either no change or an increase in ETR $_{\max }$ in response to OA (Brading et al., 2011; Fu et al., 2007; Kim et al., 2013). In our current study, $I_{k}$ increased in concert with ETR $\mathrm{max}_{\max }$, with increasing $p \mathrm{CO}_{2}$ (Table 3). This $I_{k}$-dependent behaviour is known as acclimation to higher light levels in order to optimize balanced growth (Behrenfeld et al., 2008). In the current case, the increase in $I_{k}$ under OA could indicate that eased carbon acquisition shifted the balance of energy acquisition and its sinks towards saturation at higher irradiances, which fits with the reduced Chl $a$ quota under these conditions (Fig. 2). At the same time, the light harvesting efficiency at low light $(\alpha$; please note this unit is per photosystem) also decreased in response to OA (Table 3). Such $I_{k}$-independent behaviour is influenced by changes in the relative contribution of different sinks of photosynthetic energy, namely carbon fixation, direct use, and ATP generation via cyclic electron transport and other mechanisms (Behrenfeld et al., 2008). Both photoacclimative strategies mimicked acclimation to high light in response to increasing $p \mathrm{CO}_{2}$, which may be a general OA response of phytoplankton (e.g. Hoppe et al., 2015; Rokitta et al., 2012). At the same time, reduced Chl $a$ quotas indicate that such efficient photosystems decrease the need to invest into the total number of them. This potentially balances the reductive pressure on the entire cell, as we did not observe any high-light stress, even during peaks (Fig. 3). Although there was a significant increase in $\mathrm{H}_{2} \mathrm{O}_{2}$ concentration under $\mathrm{OA}$ relative to ambient $p \mathrm{CO}_{2}$ levels, no change in $\cdot \mathrm{O}_{2}^{-}$concentration was observed (Fig. 3). Thus, even if ROS production was enhanced under $\mathrm{OA}$, efficient detoxification mechanisms (e.g. reduction of $\cdot \mathrm{O}_{2}^{-}$to $\mathrm{H}_{2} \mathrm{O}_{2}$; Asada, 1999) seem to be in place. Additionally, changes to $\mathrm{H}_{2} \mathrm{O}_{2}$ concen- tration have been linked to changes in growth metabolism under non-stressful conditions (Kim et al., 2004), which would fit with the $I_{k}$-independent behaviour observed here and suggests that sufficient sinks for the enhanced flow of photosynthetic energy were present. Thus, there is ample evidence that, despite no effect on biomass build-up, elevated $p \mathrm{CO}_{2}$ facilitated carbon acquisition and led to faster and eased photosynthetic energy generation and higher rates of cell division.

The described changes in photoacclimation were not partnered with a significant increase in POC production, despite an increase in growth rate (Fig. 2). These findings contrast with Hoppe et al. (2018), who reported that POC production rates of $M$. pusilla were generally increased under OA. In this earlier study, however, the Chl $a$ quota of $M$. pusilla remained relatively constant over a large range of $p \mathrm{CO}_{2}$ levels at two temperatures, so OA effects on the ratio between energy allocated into photosynthesis (i.e. Chl $a$ ) and biomass build-up (i.e. POC) in both studies actually agree. Furthermore, if only the $p \mathrm{CO}_{2}$ levels investigated in the current study are considered from Hoppe et al. (2018), varying OA responses (i.e. decreasing vs. increasing for POC production, and constant vs. increasing for the $\mathrm{Chl} a$ quota) were observed depending on the applied temperatures. This hints at the well-known fact that even small changes in the environmental conditions can greatly modulate OA responses of phytoplankton (Riebesell and Gattuso, 2015; Rost et al., 2008). In fact, differences between the two studies could also be caused by differences in the average irradiances (approx. 80 vs. $150 \mu \mathrm{mol}$ photons $\mathrm{m}^{-2} \mathrm{~s}^{-1}$ ). Despite these differences, one should note, however, that high growth rates were obtained under the various OA treatments. As growth rate is the best available fitness indicator for single-strain studies (Schaum and Collins, 2014), our findings are indicative of improved fitness of M. pusilla under OA.

\subsection{M. pusilla's response does not indicate interactions between light regime and $p \mathrm{CO}_{2}$}

The interaction between light field and OA has been investigated for the coccolithophore Gephyrocapsa oceanica (Jin et al., 2013) and the Antarctic diatom Chaetoceros debilis (Hoppe et al., 2015). In both studies, the species increased their photochemical performance in response to elevated $p \mathrm{CO}_{2}$ under constant light. Dynamic light fields reversed the positive effect of high $p \mathrm{CO}_{2}$, which was explained by increased high-light stress under OA and a reduction in the energy transfer efficiency from photochemistry to biomass build-up (Hoppe et al., 2015). In the current study, there was no significant interaction between light regime and $p \mathrm{CO}_{2}$ ( $p>0.05$; Figs. 2, 3; Tables 2, 3). These opposing responses could be caused by group- or species-specific differences in carbon acquisition. Diatoms, for example, have highly effective CCMs (Burkhardt et al., 2001), which are energetically expensive (Hopkinson et al., 2011). As CCMs 
allow cells to efficiently sink energy under sudden high light (Rost et al., 2006), their downregulation in response to high $p \mathrm{CO}_{2}$ can reduce the ability of cells to deal with high-light stress under OA (Hoppe et al., 2015). In contrast to other groups or taxa, which were often found to lose their ability to cope with excess energy under OA and dynamic light (e.g. Gao et al., 2012), M. pusilla maintained effective acclimation without photoinactivation under these conditions. This could be attributed to its size, making it less reliant on CCMs as a mechanism to reduce reductive pressure under high light, as well as to the observed high plasticity in its photophysiological characteristics under dynamic light (Table 3).

In conclusion, the photoacclimation strategies of $M$. pusilla were optimized for the dynamic light field, and, as this species seems less dependent on CCMs, the previously described interaction between $p \mathrm{CO}_{2}$ and dynamic light (Gao et al., 2012; Hoppe et al., 2015; Jin et al., 2013) was not observed here. This highlights that, depending on their various physiological traits, phytoplankton groups may display different types of interactive responses. It is therefore crucial to understand the underlying physiological mechanisms of observed multi-driver responses in order to judge whether generalizations based on individual studies are feasible or not.

\subsection{Implications for the future Arctic Ocean}

The findings of this study highlight the importance of considering a dynamic light field in laboratory studies. While the interaction between OA and other factors, such as higher temperature, can easily be tested in the lab (Hoppe et al., 2018), light treatments are generally less representative of in situ conditions. The difficulty of measuring and simulating more realistic variations in light has led to the common use of constant light fields, which may substantially alter numerous parameters including growth rates and underestimate the energetic costs of photoacclimation under in situ conditions (Köhler et al., 2018). Therefore, dynamic light fields need to be included when predicting future ecosystem functioning. If the responses of the strain used in this study are representative for this species, M. pusilla can be expected to cope well with a dynamic light field typical of the surface mixed layer (Tables 2, 3). While phytoplankton were often found to suffer from OA under dynamic light (Gao et al., 2012; Hoppe et al., 2015; Jin et al., 2013), M. pusilla benefitted slightly from OA irrespective of the light treatment applied. As beneficial effects by OA were also evident under different temperatures (Hoppe et al., 2018), we can conclude that M. pusilla has a high plasticity towards OA, warming and difference in light regimes, making it well adapted for conditions expected for the future Arctic Ocean. The observed high physiological plasticity, i.e. the ability to adjust physiologically to maintain high growth and/or biomass build-up under all tested scenarios, may thus also explain why picoeukaryotes are often found to dominate mesocosm assemblages under OA (Brussaard et al., 2013; Engel et al., 2008; Schulz et al., 2017).
Global warming is, due to the phenomenon of Arctic amplification (Screen and Simmonds, 2010), a particularly important driver for Arctic phytoplankton. M. pusilla has been shown to synergistically benefit from OA and warming (Hoppe et al., 2018), but the results of this study suggest that future phytoplankton studies should also investigate whether responses differ under dynamic light and determine the mechanisms, metabolic costs and trade-offs associated with interacting physiological processes. Furthermore, warming causes ocean freshening (Peterson et al., 2002) and enhanced stratification that further reduce nutrient availability (Steinacher et al., 2010). Picoeukaryotes may also benefit from these anticipated changes in nutrient supply due to their high surface : volume ratio, allowing for effective nutrient uptake (Li et al., 2009). Additionally, nutrient uptake may be facilitated by lower $\mathrm{pH}$ under elevated $p \mathrm{CO}_{2}$ (Bach et al., 2017). Nutrient deficiency was not addressed in this study as the experimental design was aiming to mimic non-limiting nutrient conditions before the spring bloom. Nonetheless, the often limiting nutrient supply in the Arctic sets the trophic status of each region and limits annual productivity (Tremblay et al., 2015) and thus is an important factor to consider in future studies. Changes in the community size structure are biogeochemically important as picoplankton-dominated systems tend to be less efficient with respect to carbon export to depth (Worden et al., 2015). If smaller phytoplankton become more dominant in the Arctic pelagic food web, this may benefit smaller grazers. With these additional steps in the food web, energy transfer efficiency to top predators as well as into the deep ocean will likely decrease (Brussaard et al., 2013). Based on the current study, an increased abundance of $M$. pusilla under future $p \mathrm{CO}_{2}$ levels can be expected not only for the more stable low-light environments but also for the productive mixed layer in springtime with its dynamic light fields.

Data availability. The dataset for this study is available from the PANGAEA data library, with the identifier https://doi.org/10.1594/ PANGAEA.908691 (White et al., 2019).

Supplement. The supplement related to this article is available online at: https://doi.org/10.5194/bg-17-635-2020-supplement.

Author contributions. CJMH designed and supervised the study. EW conducted the research and wrote the paper with contributions from CJMH and BR.

Competing interests. The authors declare that they have no conflict of interest. 
Acknowledgements. We are grateful for field support from the 2014/2015 station team of the AWIPEV Base in Ny-Ålesund (Svalbard) as well as for Klara K. E. Wolf's help with strain isolation and maintenance of M. pusilla cultures. Laura Wischnewski, Christine Schallenberg, Tina Brenneis and Marcel Machnik are acknowledged for assistance in the laboratory.

Financial support. The article processing charges for this openaccess publication were covered by a research centre of the Helmholtz Association.

Review statement. This paper was edited by Carol Robinson and reviewed by Douglas Campbell, Lennart Bach and one anonymous referee.

\section{References}

AMAP: AMAP Assessment 2018: Arctic Ocean Acidifcation, Arctic Monitoring and Assessment Programme (AMAP), Troms $\emptyset$, Norway, 187 pp., 2018.

Apel, K. and Hirt, H.: Reactive oxygen species: metabolism, oxidative stress, and signal transduction, Annu. Rev. Plant Biol., 55, 373-399, https://doi.org/10.1146/annurev.arplant.55.031903.141701, 2004.

Arrigo, K. R., van Dijken, G., and Pabi, S.: Impact of a shrinking Arctic ice cover on marine primary production, Geophys. Res. Lett., 35, L19603, https://doi.org/10.1029/2008GL035028, 2008.

Asada, K.: The water-water cycle in chloroplasts: Scavenging of Active Oxygens and Dissipation of Excess Photons, Annu. Rev. Plant Phys., 50, 601-639, https://doi.org/10.1146/annurev.arplant.50.1.601, 1999.

Bach, L. T., Mackinder, L. C., Schulz, K. G., Wheeler, G., Schroeder, D. C., Brownlee, C., and Riebesell, U.: Dissecting the impact of $\mathrm{CO}_{2}$ and $\mathrm{pH}$ on the mechanisms of photosynthesis and calcification in the coccolithophore Emiliania huxleyi, New. Phytol., 199, 121-134, https://doi.org/10.1111/nph.12225, 2013.

Bach, L. T., Alvarez-Fernandez, S., Hornick, T., Stuhr, A., and Riebesell, U.: Simulated ocean acidification reveals winners and losers in coastal phytoplankton, PloS One, 12, e0188198, https://doi.org/10.1371/journal.pone.0188198, 2017.

Badger, M. R., Andrews, T. J., Whitney, S. M., Ludwig, M., Yellowlees, D. C., Leggat, W., and Price, G. D.: The diversity and coevolution of Rubisco, plastids, pyrenoids, and chloroplastbased $\mathrm{CO}_{2}$-concentrating mechanisms in algae, Can. J. Bot., 76, 1052-1071, https://doi.org/10.1139/b98-074, 1998.

Bates, N. R. and Mathis, J. T.: The Arctic Ocean marine carbon cycle: evaluation of air-sea $\mathrm{CO}_{2}$ exchanges, ocean acidification impacts and potential feedbacks, Biogeosciences, 6, 2433-2459, https://doi.org/10.5194/bg-6-2433-2009, 2009.

Behrenfeld, M. J., Prasil, O., Kolber, Z. S., Babin, M., and Falkowski, P. G.: Compensatory changes in photosystem II electron turnover rates protect photosynthesis from photoinhibition, Photosynth. Res., 58, 259-268, https://doi.org/10.1023/A:1006138630573, 1998.
Behrenfeld, M. J., Halsey, K. H., and Milligan, A. J.: Evolved physiological responses of phytoplankton to their integrated growth environment, Philos. T. R. Soc. Lon. B, 363, 2687-2703, https://doi.org/10.1098/rstb.2008.0019, 2008.

Benov, L., Sztejnberg, L., and Fridovich, I.: Critical evaluation of the use of hydroethidine as a measure of superoxide anion radical, Free Radical Bio. Med., 25, 826-831, https://doi.org/10.1016/S0891-5849(98)00163-4, 1998.

Blankenship, R. E.: Molecular mechanisms of photosynthesis, 2nd Edn., Wiley Blackwell, USA, 2014.

Boelen, P., van de Poll, W. H., van der Strate, H. J., Neven, I. A., Beardall, J., and Buma, A. G.: Neither elevated nor reduced $\mathrm{CO}_{2}$ affects the photophysiological performance of the marine Antarctic diatom Chaetoceros brevis, J. Exp. Mar. Biol. Ecol., 406, 38-45, https://doi.org/10.1016/j.jembe.2011.06.012, 2011.

Brading, P., Warner, M. E., Davey, P., Smith, D. J., Achterberg, E. P., and Suggett, D. J.: Differential effects of ocean acidification on growth and photosynthesis among phylotypes of Symbiodinium (Dinophyceae), Limnol. Oceanogr., 56, 927-938, https://doi.org/10.4319/lo.2011.56.3.0927, 2011.

Brewer, P. G., Bradshaw, A., and Williams, R.: Measurements of total carbon dioxide and alkalinity in the North Atlantic Ocean in 1981, in: The changing carbon cycle, Springer, New York, NY, 348-370, https://doi.org/10.1007/978-1-4757-1915-4_18, 1986.

Brussaard, C. P. D., Noordeloos, A. A. M., Witte, H., Collenteur, M. C. J., Schulz, K., Ludwig, A., and Riebesell, U.: Arctic microbial community dynamics influenced by elevated $\mathrm{CO}_{2}$ levels, Biogeosciences, 10, 719-731, https://doi.org/10.5194/bg-10719-2013, 2013.

Burkhardt, S., Amoroso, G., Riebesell, U., and Sültemeyer, D.: $\mathrm{CO}_{2}$ and $\mathrm{HCO}_{3}^{-}$uptake in marine diatoms acclimated to different $\mathrm{CO}_{2}$ concentrations, Limnol. Oceanogr., 46, 1378-1391, https://doi.org/10.4319/lo.2001.46.6.1378, 2001.

Denman, K. L. and Gargett, A. E.: Time and space scales of vertical mixing and advection of phytoplankton in the upper ocean, Limnol. Oceanogr., 28, 801-815, https://doi.org/10.4319/lo.1983.28.5.0801, 1983.

Dickson, A. G. and Millero, F. J.: A comparison of the equilibrium constants for the dissociation of carbonic acid in seawater media, Deep-Sea Res., 34, 1733-1743, https://doi.org/10.1016/01980149(87)90021-5, 1987.

Dickson, A. G., Sabine, C. L., and Christian, J. R.: Guide to best practices for ocean $\mathrm{CO}_{2}$ measurements, North Pacific Marine Science Organization, Sidney, British Columbia, 2007.

Engel, A., Schulz, K. G., Riebesell, U., Bellerby, R., Delille, B., and Schartau, M.: Effects of $\mathrm{CO}_{2}$ on particle size distribution and phytoplankton abundance during a mesocosm bloom experiment (PeECE II), Biogeosciences, 5, 509-521, https://doi.org/10.5194/bg-5-509-2008, 2008.

Falkowski, P. G.: Light-shade adaptation in marine phytoplankton, in: Primary productivity in the sea, Vol. 19, Springer, Boston, USA, 1980.

Falkowski, P. G. and Raven, J. A.: Aquatic photosynthesis, 2nd Edn., Princeton University Press, USA, 2013.

Fu, F.-X., Warner, M. E., Zhang, Y., Feng, Y., and Hutchins, D. A.: Effects of Increased Temperature and $\mathrm{CO}_{2}$ on Photosynthesis, Growth, and Elemental Ratios in Marine Synechococcus and Prochlorococcus (Cyanobacteria), J. Phycol., 43, 485-496, https://doi.org/10.1111/j.1529-8817.2007.00355.x, 2007. 
Gao, K., Helbling, E. W., Häder, D. P., and Hutchins, D. A.: Responses of marine primary producers to interactions between ocean acidification, solar radiation, and warming, Mar. Ecol.Prog. Ser., 470, 167-189, https://doi.org/10.3354/meps10043, 2012.

Granskog, M. A., Stedmon, C. A., Dodd, P. A., Amon, R. M. W., Pavlov, A. K., de Steur, L., and Hansen, E.: Characteristics of colored dissolved organic matter (CDOM) in the Arctic outflow in the Fram Strait: Assessing the changes and fate of terrigenous CDOM in the Arctic Ocean, J. Geophys. Res.-Oceans, 117, C12021, https://doi.org/10.1029/2012jc008075, 2012.

Guillard, R. R. and Ryther, J. H.: Studies of marine planktonic diatoms. I. Cyclotella nana Hustedt, and Detonula confervacea (cleve) Gran, Can. J. Microbiol., 8, 229-239, https://doi.org/10.1139/m62-029, 1962.

Hopkinson, B. M., Dupont, C. L., Allen, A. E., and Morel, F. M.: Efficiency of the $\mathrm{CO}_{2}$-concentrating mechanism of diatoms, P. Natl. Acad. Sci. USA, 108, 3830-3837, https://doi.org/10.1073/pnas.1018062108, 2011.

Hoppe, C. J., Holtz, L. M., Trimborn, S., and Rost, B.: Ocean acidification decreases the light-use efficiency in an Antarctic diatom under dynamic but not constant light, New Phytol., 207, 159171, https://doi.org/10.1111/nph.13334, 2015.

Hoppe, C. J. M., Langer, G., Rokitta, S. D., Wolf-Gladrow, D. A., and Rost, B.: Implications of observed inconsistencies in carbonate chemistry measurements for ocean acidification studies, Biogeosciences, 9, 2401-2405, https://doi.org/10.5194/bg-9-24012012, 2012.

Hoppe, C. J., Schuback, N., Semeniuk, D. M., Maldonado, M. T., and Rost, B.: Functional Redundancy Facilitates Resilience of Subarctic Phytoplankton Assemblages toward Ocean Acidification and High Irradiance, Front. Mar. Sci., 4, 229, https://doi.org/10.3389/fmars.2017.00229, 2017.

Hoppe, C. J. M., Flintrop, C. M., and Rost, B.: The Arctic picoeukaryote Micromonas pusilla benefits synergistically from warming and ocean acidification, Biogeosciences, 15, 43534365, https://doi.org/10.5194/bg-15-4353-2018, 2018.

Houghton, J., Ding, Y., and Griggs, D.: Climate Change: Scientific Basis, IPCC TAR Working Group 1, The Press Syndicate of Cambridge University, UK, 2001.

$\mathrm{Hu}$, A. and Bates, S. C.: Internal climate variability and projected future regional steric and dynamic sea level rise, Nat. Commun., 9, 1068, https://doi.org/10.1038/s41467-018-03474-8, 2018.

Huisman, J.: Population dynamics of light-limited phytoplankton: microcosm experiments, Ecology, $\quad 80, \quad 202-210, \quad$ https://doi.org/10.1890/00129658(1999)080[0202:PDOLLP]2.0.CO;2, 1999.

Iglesias-Rodriguez, M., Nimer, N., and Merrett, M.: Carbon dioxide-concentrating mechanism and the development of extracellular carbonic anhydrase in the marine picoeukaryote Micromonas pusilla, New Phytol., 140, 685-690, https://doi.org/10.1046/j.1469-8137.1998.00309.x, 1998.

Jin, P., Gao, K., Villafañe, V. E., Campbell, D. A., and Helbling, W.: Ocean acidification alters the photosynthetic responses of a coccolithophorid to fluctuating UV and visible radiation, Plant Physiol., 162, 2084-2094, https://doi.org/10.1104/pp.113.219543, 2013.

Kim, D., Watanabe, M., Nakayasu, Y., and Kohata, K.: Production of superoxide anion and hydrogen peroxide associated with cell growth of Chattonella antiqua, Aquat. Microb. Ecol., 35, 57-64, https://doi.org/10.3354/ame035057, 2004.

Kim, J.-H., Kim, K. Y., Kang, E. J., Lee, K., Kim, J.-M., Park, K.-T., Shin, K., Hyun, B., and Jeong, H. J.: Enhancement of photosynthetic carbon assimilation efficiency by phytoplankton in the future coastal ocean, Biogeosciences, 10, 7525-7535, https://doi.org/10.5194/bg-10-7525-2013, 2013.

Klughammer, C. and Schreiber, U.: Complementary PS II quantum yields calculated from simple fluorescence parameters measured by PAM fluorometry and the Saturation Pulse method, PAM Appl. Notes, 1, 27-35, 2008.

Knap, A., Michaels, A., Close, A., Ducklow, H., and Dickson, A.: Protocols for the Joint Global Ocean Flux Study (JGOFS) Core Measurements, UNESCO, Paris, France, 170 pp., 1996.

Köhler, J., Wang, L., Guislain, A., and Shatwell, T.: Influence of vertical mixing on light-dependency of phytoplankton growth, Limnol. Oceanogr., 63, 1156-1167, https://doi.org/10.1002/lno.10761, 2018.

Kolber, Z. S., Prášil, O., and Falkowski, P. G.: Measurements of variable chlorophyll fluorescence using fast repetition rate techniques: defining methodology and experimental protocols, BBABioenergetics, 1367, 88-106, https://doi.org/10.1016/S00052728(98)00135-2, 1998.

Kramer, D. M., Johnson, G., Kiirats, O., and Edwards, G. E.: New fluorescence parameters for the determination of QA redox state and excitation energy fluxes, Photosynth. Res., 79, 209-218, https://doi.org/10.1023/B:PRES.0000015391.99477.0d, 2004.

Li, W. K., McLaughlin, F. A., Lovejoy, C., and Carmack, E. C.: Smallest algae thrive as the Arctic Ocean freshens, Science, 326, 539-539, https://doi.org/10.1126/science.1179798, 2009.

Litchman, E.: Growth rates of phytoplankton under fluctuating light, Freshwater Biol., 44, 223-235, https://doi.org/10.1046/j.1365-2427.2000.00559.x, 2000.

Litchman, E., Klausmeier, C. A., and Bossard, P.: Phytoplankton nutrient competition under dynamic light regimes, Limnol. Oceanogr., 49, 1457-1462, https://doi.org/10.4319/lo.2004.49.4_part_2.1457, 2004.

Lohbeck, K. T., Riebesell, U., and Reusch, T. B.: Adaptive evolution of a key phytoplankton species to ocean acidification, Nat. Geosci., 5, 346, https://doi.org/10.1038/ngeo1441, 2012.

Lovejoy, C., Vincent, W. F., Bonilla, S., Roy, S., Martineau, M. J., Terrado, R., Potvin, M., Massana, R., and PedrósAlió, C.: Distribution, phylogeny, and growth of cold-adapted picoprasinophytes in Arctic Seas, J. Phycol., 43, 78-89, https://doi.org/10.1111/j.1529-8817.2006.00310.x, 2007.

Maat, D. S., Crawfurd, K. J., Timmermans, K. R., and Brussaard, C. P.: Elevated $p \mathrm{CO}_{2}$ and phosphate limitation favor Micromonas pusilla through stimulated growth and reduced viral impact, Appl. Environ. Microb., 80, 3119-3127, https://doi.org/10.1128/AEM.03639-13., 2014.

MacIntyre, H. L., Kana, T. M., and Geider, R. J.: The effect of water motion on short-term rates of photosynthesis by marine phytoplankton, Trends Plant Sci., 5, 12-17, https://doi.org/10.1016/S1360-1385(99)01504-6, 2000.

Marquardt, M., Vader, A., Stübner, E. I., Reigstad, M., and Gabrielsen, T. M.: Strong seasonality of marine microbial eukaryotes in a high-arctic fjord (Isfjorden, in West Spitsbergen, Norway), Appl. Environ. Microb., 82, 1868-1880, https://doi.org/10.1128/AEM.03208-15, 2016. 
McKie-Krisberg, Z. M. and Sanders, R. W.: Phagotrophy by the picoeukaryotic green alga Micromonas: implications for Arctic Oceans, ISME J., 8, 1953-1961, https://doi.org/10.1038/ismej.2014.16, 2014.

Meakin, N. G. and Wyman, M.: Rapid shifts in picoeukaryote community structure in response to ocean acidification, ISME J., 5, 1397-1405, https://doi.org/10.1038/ismej.2011.18, 2011.

Mehrbach, C., Culberson, C., Hawley, J., and Pytkowicx, R.: Measurement of the apparent dissociation constants of carbonic acid in seawater at atmospheric pressure, Limnol. Oceanogr., 18, 897907, https://doi.org/10.4319/lo.1973.18.6.0897, 1973.

Miller, G. H., Alley, R. B., Brigham-Grette, J., Fitzpatrick, J. J., Polyak, L., Serreze, M. C., and White, J. W.: Arctic amplification: can the past constrain the future?, Quaternary Sci. Rev., 29, 1779-1790, https://doi.org/10.1016/j.quascirev.2010.02.008, 2010.

Mills, M. M., Kropuenske, L. R., Van Dijken, G. L., Alderkamp, A. C., Berg, G. M., Robinson, D. H., Welschmeyer, N. A., and Arrigo, K. R.: Photophysiology in two southern ocean phytoplankton taxa: Photosynthesis of Phaeocystis Antarctica (prymnesiophyceae) and Fragilariopsis Cylindrus (bacillariophyceae) under simulated mixed-layer irradiance, J. Phycol., 46, 1114-1127, https://doi.org/10.1111/j.1529-8817.2010.00923.x, 2010.

Newbold, L. K., Oliver, A. E., Booth, T., Tiwari, B., Desantis, T., Maguire, M., Andersen, G., van der Gast, C. J., and Whiteley, A. S.: The response of marine picoplankton to ocean acidification, Environ. Microbiol., 14, 2293-2307, https://doi.org/10.1111/j.1462-2920.2012.02762.x, 2012.

Nöthig, E.-M., Bracher, A., Engel, A., Metfies, K., Niehoff, B., Peeken, I., Bauerfeind, E., Cherkasheva, A., Gäbler-Schwarz, S., and Hardge, K.: Summertime plankton ecology in Fram Strait - a compilation of long-and short-term observations, Polar Res., 34, 23349, https://doi.org/10.3402/polar.v34.23349, 2015.

Oxborough, K. and Baker, N. R.: Resolving chlorophyll $a$ fluorescence images of photosynthetic efficiency into photochemical and non-photochemical components - calculation of $q P$ and $F_{\mathrm{v}}^{\prime} / F_{\mathrm{m}}^{\prime}$; without measuring $F_{\mathrm{o}}^{\prime}$, Photosynth. Res., 54, 135-142, https://doi.org/10.1023/A:1005936823310, 1997.

Oxborough, K., Moore, C. M., Suggett, D. J., Lawson, T., Chan, H. G., and Geider, R. J.: Direct estimation of functional PSII reaction center concentration and PSII electron flux on a volume basis: a new approach to the analysis of Fast Repetition Rate fluorometry (FRRf) data, Limnol. Oceanogr.-Meth., 10, 142-154, https://doi.org/10.4319/lom.2012.10.142, 2012.

Pachauri, R. K., Allen, M. R., Barros, V. R., Broome, J., Cramer, W., Christ, R., Church, J. A., Clarke, L., Dahe, Q., and Dasgupta, P.: Climate change 2014: synthesis report. Contribution of Working Groups I, II and III to the fifth assessment report of the Intergovernmental Panel on Climate Change, IPCC, Geneva, Switzerland, 2014.

Palmer, M. A., Van Dijken, G. L., Mitchell, B. G., Seegers, B. J., Lowry, K. E., Mills, M. M., and Arrigo, K. R.: Light and nutrient control of photosynthesis in natural phytoplankton populations from the Chukchi and Beaufort seas, Arctic Ocean, Limnol. Oceanogr., 58, 2185-2205, https://doi.org/10.4319/1o.2013.58.6.2185, 2013.

Peterson, B. J., Holmes, R. M., McClelland, J. W., Vorosmarty, C. J., Lammers, R. B., Shiklomanov, A. I., Shiklomanov, I. A., and Rahmstorf, S.: Increasing river dis- charge to the Arctic Ocean, Science, 298, 2171-2173, https://doi.org/10.1126/science.1077445, 2002.

Pierrot, D., Lewis, E., and Wallace, D.: MS Excel program developed for $\mathrm{CO}_{2}$ system calculations, ORNL/CDIAC-105a. Carbon Dioxide Information Analysis Center, Oak Ridge National Laboratory, US Department of Energy, Oak Ridge, Tennessee, 2006.

Pörtner, H.-O., Karl, D. M., Boyd, P. W., Cheung, W., Lluch-Cota, S. E., Nojiri, Y., Schmidt, D. N., Zavialov, P. O., Alheit, J., and Aristegui, J.: Ocean systems, in: Climate change 2014: impacts, adaptation, and vulnerability. Part A: global and sectoral aspects, Contribution of working group II to the fifth assessment report of the intergovernmental panel on climate change, Cambridge University Press, 411-484, Cambridge, UK and NY, USA, 2014.

Prado, R., Rioboo, C., Herrero, C., Suarez-Bregua, P., and Cid, A.: Flow cytometric analysis to evaluate physiological alterations in herbicide-exposed Chlamydomonas moewusii cells, Ecotoxicology, 21, 409-420, https://doi.org/10.1007/s10646-011-08013, 2012.

Ragni, M., Airs, R. L., Leonardos, N., and Geider, R. J.: Photoinhibition of PSII in Emiliania Huxleyi (Haptophyta) under High Light Stress: The Roles of Photoacclimation, Photoprotection, and Photorepair, J. Phycol., 44, 670-683, https://doi.org/10.1111/j.1529-8817.2008.00524.x, 2008.

Reinfelder, J. R.: Carbon concentrating mechanisms in eukaryotic marine phytoplankton, Annu. Rev. Mar. Sci., 3, 291-315, https://doi.org/10.1146/annurev-marine-120709-142720, 2011.

Riebesell, U. and Gattuso, J.-P.: Lessons learned from ocean acidification research, Nat. Clim. Change, 5, 12-14, 2015.

Riebesell, U. and Tortell, P. D.: Effects of ocean acidification on pelagic organisms and ecosystems, Ocean acidification, Oxford University Press, Oxford, UK, 2011.

Rokitta, S. D., John, U., and Rost, B.: Ocean acidification affects redox-balance and ion-homeostasis in the life-cycle stages of Emiliania huxleyi, PLoS One, 7, 1-10, e52212, https://doi.org/10.1371/journal.pone.0052212, 2012.

Rost, B., Riebesell, U., and Sültemeyer, D.: Carbon acquisition of marine phytoplankton: effect of photoperiod length, Limnol. Oceanogr., 51, 12-20, https://doi.org/10.4319/lo.2006.51.1.0012, 2006.

Rost, B., Zondervan, I., and Wolf-Gladrow, D.: Sensitivity of phytoplankton to future changes in ocean carbonate chemistry: current knowledge, contradictions and research directions, Mar. Ecol.Prog. Ser., 373, 227-237, https://doi.org/10.3354/meps07776, 2008.

Schaum, C. E. and Collins, S.: Plasticity predicts evolution in a marine alga, Proc. Biol. Sci., 281, 20141486, https://doi.org/10.1098/rspb.2014.1486, 2014.

Schaum, E., Rost, B., Millar, A. J., and Collins, S.: Variation in plastic responses of a globally distributed picoplankton species to ocean acidification, Nat. Clim. Change, 3, 298-302, https://doi.org/10.1038/nclimate1774, 2012.

Schuback, N., Hoppe, C. J., Tremblay, J. É., Maldonado, M. T., and Tortell, P. D.: Primary productivity and the coupling of photosynthetic electron transport and carbon fixation in the Arctic Ocean, Limnol. Oceanogr., 62, 898-921, https://doi.org/10.1002/lno.10475, 2017.

Schulz, K. G., Bach, L. T., Bellerby, R. G., Bermúdez, R., Büdenbender, J., Boxhammer, T., Czerny, J., Engel, A., Ludwig, A., and Meyerhöfer, M.: Phytoplankton blooms at in- 
creasing levels of atmospheric carbon dioxide: Experimental evidence for negative effects on prymnesiophytes and positive on small picoeukaryotes, Front. Mar. Sci., 4, 64, https://doi.org/10.3389/fmars.2017.00064, 2017.

Screen, J. A. and Simmonds, I.: The central role of diminishing sea ice in recent Arctic temperature amplification, Nature, 464, 1334, https://doi.org/10.1038/nature09051, 2010.

Shatwell, T., Nicklisch, A., and Köhler, J.: Temperature and photoperiod effects on phytoplankton growing under simulated mixed layer light fluctuations, Limnol. Oceanogr., 57, 541-553, https://doi.org/10.4319/lo.2012.57.2.0541, 2012.

Steinacher, M., Joos, F., Frölicher, T. L., Bopp, L., Cadule, P., Cocco, V., Doney, S. C., Gehlen, M., Lindsay, K., Moore, J. K., Schneider, B., and Segschneider, J.: Projected 21st century decrease in marine productivity: a multi-model analysis, Biogeosciences, 7, 979-1005, https://doi.org/10.5194/bg-7-979-2010, 2010.

Stoll, M., Bakker, K., Nobbe, G., and Haese, R.: Continuousflow analysis of dissolved inorganic carbon content in seawater, Anal. Chem., 73, 4111-4116, https://doi.org/10.1021/ac010303r, 2001.

$\mathrm{Su}$, W., Jakob, T., and Wilhelm, C.: The Impact of Nonphotochemical Quenching of Fluorescence on the Photon Balance in Diatoms under Dynamic Light Conditions, J. Phycol., 48, 336-346, https://doi.org/10.1111/j.1529-8817.2012.01128.x, 2012.

Suggett, D. J., Le Floc'H, E., Harris, G. N., Leonardos, N., and Geider, R. J.: Different strategies of photoacclimation by two strains of Emiliania huxleyi (Haptophyta), J. Phycol., 43, 1209-1222, https://doi.org/10.1111/j.1529-8817.2007.00406.x, 2007.

Talmy, D., Blackford, J., Hardman-Mountford, N. J., Dumbrell, A. J., and Geider, R. J.: An optimality model of photoadaptation in contrasting aquatic light regimes, Limnol. Oceanogr., 58, 18021818, https://doi.org/10.4319/lo.2013.58.5.1802, 2013.

Tremblay, J.-É., Anderson, L. G., Matrai, P., Coupel, P., Bélanger, S., Michel, C., and Reigstad, M.: Global and regional drivers of nutrient supply, primary production and $\mathrm{CO}_{2}$ drawdown in the changing Arctic Ocean, Prog. Oceanogr., 139, 171-196, https://doi.org/10.1016/j.pocean.2015.08.009, 2015.

Trenberth, K., Jones, P., Ambenje, P., Bojariu, R., Easterling, D., Klein Tank, A., Parker, D., Rahimzadeh, F., Renwick, J., and Rusticucci, M.: Observations: surface and atmospheric climate change, in: Climate Change 2007: The Physical Science Basis. Contribution of Working Group I to the Fourth Assessment Report of the Intergovernmental Panel on Climate Change, Cambridge University Press, 235-336, Cambridge, UK and NY, USA, 2007.
Trimborn, S., Thoms, S., Petrou, K., Kranz, S. A., and Rost, B.: Photophysiological responses of Southern Ocean phytoplankton to changes in $\mathrm{CO}_{2}$ concentrations: short-term versus acclimation effects, J. Exp. Mar. Biol. Ecol., 451, 44-54, https://doi.org/10.1016/j.jembe.2013.11.001, 2014.

Uppström, L. R.: The boron/chlorinity ratio of deep-sea water from the Pacific Ocean, Deep-Sea Res. Oceanogr. Abstr., 21, 161-162, https://doi.org/10.1016/0011-7471(74)90074-6, 1974.

Van Leeuwe, M. and Stefels, J.: Photosynthetic responses in Phaeocystis antarctica towards varying light and iron conditions, in: Phaeocystis, major link in the biogeochemical cycling of climate-relevant elements, Springer, 61-70, https://doi.org/10.1007/978-1-4020-6214-8_6, 2007.

Wagner, H., Jakob, T., and Wilhelm, C.: Balancing the energy flow from captured light to biomass under fluctuating light conditions, New Phytol., 169, 95-108, https://doi.org/10.1111/j.14698137.2005.01550.x, 2006.

Wassmann, P. and Reigstad, M.: Future Arctic Ocean seasonal ice zones and implications for pelagic-benthic coupling, Oceanography, 24, 220-231, https://doi.org/10.5670/oceanog.2011.74, 2011.

Webb, W. L., Newton, M., and Starr, D.: Carbon dioxide exchange of Alnus rubra: A mathematical model, Oecologia, 17, 281-291, https://doi.org/10.1007/BF00345747, 1974.

White, E., Hoppe, C. J., and Rost, B.: The Arctic picoeukaryote Micromonas pusilla benefits from Ocean Acidification under constant and dynamic light, PANGAEA, https://doi.org/10.1594/PANGAEA.908691, 2019.

Worden, A. Z., Follows, M. J., Giovannoni, S. J., Wilken, S., Zimmerman, A. E., and Keeling, P. J.: Rethinking the marine carbon cycle: factoring in the multifarious lifestyles of microbes, Science, 347, 1257594, https://doi.org/10.1126/science.1257594, 2015.

Xu, K., Grant-Burt, J. L., Donaher, N., and Campbell, D. A.: Connectivity among Photosystem II centers in phytoplankters: Patterns and responses, BBA-Bioenergetics, 1858, 459-474, https://doi.org/10.1016/j.bbabio.2017.03.003, 2017. 